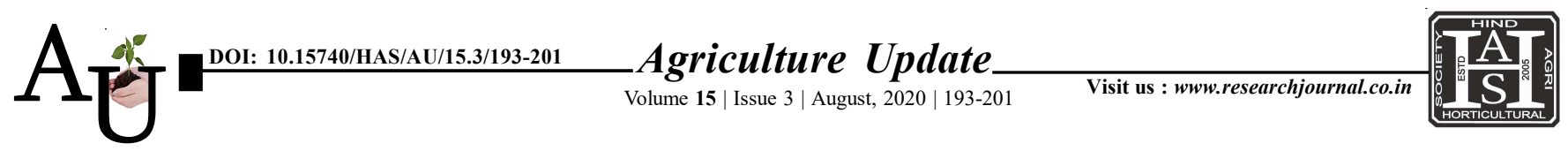

ISSN-0973-1520

\title{
Research Article: Farmer field school : An approach beyond technology transfer
}

Article Chronicle:

Received :

29.05.2020;

Revised:

10.06.2020;

Accepted :

11.07.2020

Key Words :

Farmer field school, FFS, IPM, Extension approaches, Participatory, Facilitator

\section{Amandeep Singh, Dharminder Singh and R. K. Dhaliwal}

SUMMARY : Farmer field school is an innovative extension approach, emerged in rice crop and gradually diversified to vegetables, cotton, livestock and other crops. FFS originated from Indonesia, is presently being conducted in many countries with local adaptations and institutionalization. FFS is a groupbased learning process that includes hands-on training methods, carried out through field observations, agro-ecosystem analysis at subgroup level, agro-ecosystem analysis at school level and special topics. Participants of farmer field schools are made to learn through direct real-life experiences to maximize retention of farm information. During the period 1994-2013, total 14,617 FFS were organized to train 58,422 agricultural extension officers and 4,39,508 farmers in the country. Evaluation studies reported that the FFS approach has empowered farmers in knowledge acquisition, analytical skills, critical thinking, problem-solving skills and reflecting an increase in yield, reduction in pesticide use and farm-level returns. Sustained diffusion from field school graduates to neighboring farmers still lacks convincing evidences. Effective FFS essentially require backstopping by experienced facilitators, appropriate fund release mechanism, proper logistics, regular monitoring and participation of farmers.

How to cite this article : Singh, Amandeep, Singh, Dharminder and Dhaliwal, R.K. (2020). Farmer field school: An approach beyond technology transfer. Agric. Update, 15(3): 193-201; DOI : 10.15740/HAS/AU/15.3/193201. Copyright@2020: Hind Agri-Horticultural Society.
Author for correspondence :

Amandeep Singh Department of Extension Education, Punjab Agricultural University, Ludhiana (Punjab) India

Email: amanduggan98@ gmail.com

See end of the article for authors' affiliations 